\title{
CALL FOR PAPER
}

Välkomna att skicka in bidrag till nästa specialnummer

\section{PANDEMINS SPÅR \\ - Socialvetenskapliga perspektiv på Covid-19}

Covid-19-pandemin överraskade världen. Det som började som ett till synes småskaligt utbrott i en provins i Kina utvecklades snabbt globalt och definierades som en pandemi i mars 2020. Covid-19 har spridit sig och fall konstaterats i nästan alla världens länder under våren och sommaren 2020.

Covid-19 utgör eft hot och utmaning eftersom det är eft helt nytt virus. Vid utbrottets början fanns ingen kunskap om denna typ av coronavirus. Kunskapsinhämtandet har emellertid gått snabbt och forskning pågår intensivt inom många discipliner och områden.

I en globaliserad värld har Covid-19 inneburit att många drabbade länder stängt gränser och försökt skydda sin befolkning genom isolering. Lockdown infördes till att börja med i Kina och följdes därefter av allt fler länder och har nu kommit att bli den standardlösning som drabbade länder väljer. Lockdown genomförs i olika modeller, med mer eller mindre hårda krav på medborgare att hålla sig hemma. Retoriken blev allt kraftigare när politiker sökte motivera befolkningen att följa restriktioner som exempelvis förbud att lämna hemmet med mindre än ett dokument som intygade syftet. Emmanuel Macron förklarade "vi är i krig" när han uffärdade dekretet om att stänga Frankrike. Polis och militär har patrullerat gator i många städer för att se till så isoleringen upprätthålls. 
Effekter av nedstängningen av samhällen är många, och vissa syns omedelbart medan andra kommer att visa sig längre fram. Det är redan omtalat i Sverige hur påfrestande isoleringen upplevts av äldre. Det finns indikationer på ökat våld i hemmet, inte minst mot kvinnor och barn, liksom ökad suicidfrekvens. Sjukvården noterade en 30-procentig minskning av vårdsökande för allvarliga hälsotillstånd som hiärtinfarkt och stroke, men även upptäckter av misstänkta knölar. Många planerade operationer och annan form av behandlingar har ställts in eller skjutits fram i tiden.

I Covid-19:s spår har vi sett ett excellerande i nationell statistik och jämförelser mellan länder i alla typer av media. Allt har jämförts men ofta utan kvalitetssäkrat underlag, rigorösa definitioner och sakliga grunder.

Vi kan notera att mitt i Covid-19 pandemin växer nationalismen över hela världen, och inte bara genom mer och fler gränser. Länder jämförs och regeringar jämför sig och måttet på hur bra de bekämpar pandemin är antalet avlidna Covid-19-patienter (om det är en direkt följd av Covid-19 eller av andra orsaker är ofta hölit i dunkel). Coronaviruset är en inkräktare från andra länder med potential att göra den egna befolkningen sjuk, och hotet från "De Andra" förstärks, vilket inte minst personer som bor på andra sidan en nationsgräns har fått erfara.

Även om liknande epidemier har inträffat tidigare som fallet är med sars, ebola och svininfluensaepidemin, menar forskare, politiker, ekonomer, m.fl. att storleken och den ekonomiska effekten av Covid-

19-pandemin är den i särklass allvarligaste. Covid-19 pandemin är en händelse som vissa experter jämför med den stora depressionen 1929 och finanskrisen 2007-2008 i termer av dess inverkan på ekonomin nationellt och globalt med många socioekonomiska konsekvenser. Flera forskare har redan konstaterat att pandemin har förvärrat den ekonomiska ojämlikheten. Samtidigt har Covid-19 också visat på möjligheter för EU såväl som stater att genomföra mycket stora offentliga interventioner i ekonomin. En ekonomisk kris som denna kan komma att skapa bestående förändringar i prefer- 
enser och förväntningar hos människor, företag och organisationer.

Det är högst troligt att konsekvenserna av Covid-19-pandemin kommer att vara betydande, utbredda och pågå under lång tid.

Ett exempel på detta är signalerna från Folkhälsomyndigheten och WHO att coronavirus är något vi måste lära oss att leva med för lång tid framöver. Hittills har det haft enorma effekter på samhällen. När vi nu anpassar oss till denna situation bör vi fundera över vad denna pandemi kommer att innebära för samhället.

Vår utgångspunkt är att samhällsvetenskap kan lämna ett viktigt bidrag för att förstå relationen mellan Covid-19 och samhället. Den ackumulerade kunskapen är i nuläget inte tillräcklig för att uppskatta de kortsiktiga och långsiktiga konsekvenserna av Covid-19pandemin. Men vissa tendenser går redan nu att urskilja som kan bidra till kunskap om vilka sociala utmaningar och möjligheter vi står inför. Socialvetenskaplig tidskrift vill lämna ett bidrag i den riktningen.

När vi i framtiden förhoppningsvis långsamt återgår till någon sorts normalitet kommer både beslutsfattare, praktiker och allmänheten att behöva tillförlitliga kunskaper, däribland från samhällsvetenskaplig forskning.

\section{Temanumret har särskilt fokus på...}

Mot denna bakgrund inbjuder vi forskare att skicka in samhällsvetenskapliga analyser om pandemin. Vi välkomnar forskare inom samhällsvetenskap att lämna in sina empiriska eller teoretiska studier i det temanummer som SVT ska publicera. I synnerhet uppmuntrar vi studier som erbjuder en grundlig förståelse av de utmaningar som välfärdsinstitutioner och välfärdsarbetare står inför.

Vi är intresserade av att främja den vetenskapliga diskussionen om effekterna - kortsiktiga och långsiktiga - av Covid-19-pandemin med avseende på samhälleliga utmaningar och sociala problem och hur de kan bemötas. Därför välkomnar vi innovativa bidrag om den 
senaste tidens utveckling och de förändringar som samhället på olika nivåer (från det globala till det lokala) för närvarande genomgår.

Vi välkomnar både empirisk forskning och teoretiska och kritiska bidrag från alla samhällsvetenskapliga eller humanistiska discipliner och vi välkomnar förstås tvärvetenskapliga reflektioner.

Syftet med specialnumret är att presentera artiklar som är relevanta för att förstå effekten av krisen som genererats av Covid-19. Välfärdsarbetare står inför uppgiften att hantera flera nya utmaningar som särskilt hårt drabbat socioekonomiskt svaga och andra sårbara grupper.

\section{För detta temanummer söker vi exempelvis paper som tar upp frågor som:}

I vilken utsträckning har pandemin förvärrat befintliga ojämlikheter i ekonomi, välfärd och hälsa? Kommer pandemin att även långsiktigt att leda till ökad ojämlikhet, t.ex. pga. kön eller etnicitet, och socio-ekonomisk exkludering?

Vilka är de hälsorelaterade, sociala och kulturella effekterna av Covid-19-pandemin för olika befolkningsgrupper såsom äldre, barn, minoriteter, låginkomsttagare, arbetslösa, hemlösa?

Vad har Covid-19 visat när det gäller äldreomsorgen? Vilken betydelse och i vilka former har privatiseringen av utförandet av välfärdstiänster och NPM som styrsystem haft på Covid-19pandemin och dess konsekvenser? Vilka problem har välfärdsarbetets praktik utsatts för av Covid-19-pandemin? Hur har grundläggande mänskliga rättigheter (t.ex. yttrandefrihet, frihet från diskriminering, värnandet av den enskildes privatliv) beaktats under Covid-19-pandemin? Hur har Covid-19-pandemin påverkat utsatta barn och ungdomar? Vad innebär pandemin och åtföljande lockdown för våld i nära relationer? Hur har välfärdsstatens skyddsnät angående vård av barn fungerat under dessa utmanande omständigheter? 
Hur har politiken och retoriken förändrats i skuggan av Covid-19?

Vilken inverkan har en ökad nationalism haft på politiken under pandemin? Har motsättningen mellan ökad nationalism i en globaliserad värld blivit tydligare i hanteringen av Covid-19?

Utvärdering av strategin för att hantera Covid-19-pandemin, t.ex. arbeta hemma, stänga skolor och universitet, förbud av besök på äldreboenden, testning m.m. Vilka är riskerna med ett stängt samhälle? Som t.ex. ekonomiska risker, risker för mental hälsa och fysisk hälsa.

Covid-19 som en vetenskaplig kontrovers. Covid-19 och tilliten till myndigheter och vetenskaplig forskning. Myndigheternas arbete och samarbete kring Covid-19.

\section{Granskningsprocess}

Manuskript ska utformas i enlighet med tidskriftens författaranvisningar (https://liu.se/artikel/socialvetenskaplig-tidskrift).

Alla handlingar måste skickas in med tydlig markering som indikerar att inlämningen av det specifika bidraget är avsett för detta specialnummer.

Skicka bidraget till: socialvetenskapligtidskrift@ikos.liu.se

Paper som lämnats in till specialutgåvan kommer att underkastas den normala granskningsprocessen.

Tidsfrist för inlämnande av paper: 28 april 2021

Tidsfrist för det första beslutet: 30 maj 2021

Slutligt beslut om manuskript: 30 november 2021

Vid frågor om specialutgåvan kontakła redaktörerna:

Carin Cuadra: carin.cuadra@mau.se

Kristofer Hansson: kristofer.hansson@mau.se

Dimitris Michailakis: dimitris.michailakis@liu.se

Anders Neergaard: anders.neergaard@liu.se 